\title{
A Comparison of Charles Taylor and Talal Asad on the Issue of Secularity
}

\author{
Ayşe Polat*
}

Talal Asad and Charles Taylor have been thinking and writing about secularism for at least one decade. Their works are widely read, discussed, and admired. They, by and large, constitute the contemporary framework of discussion for those interested in issues revolving around secularization, secularism, and the secular, which although are terms that refer to distinctive phenomena, are often misused as if they are either the same or simply aspects of the same process. However, these two scholars still hold significantly different, if not mutually contradictory, ideas about secularism. The aim of this article is not to provide a summary of their thoughts on secularism, but rather, to compare and contrast their critically different approaches to the issue of secularism. In this regard, this article argues that an unbridgeable gap exists between Asad's and Taylor's approaches to and engagements with the secular. This article first covers Taylor's and then Asad's approach and method through a close reading of Taylor's A Secular Age, and Asad's Genealogies of Religion, Formations of the Secular, and the edited volume on him, Powers of the Secular Modern.

Taylor begins A Secular Age by turning an obvious, commonly agreed experience of living in a secular age, into a question: "What does it mean to say that we live in a secular age?" (Taylor, 2007, p. 1). From the outset, he seeks to challenge this familiarity with the secular by underlining that it is not very clear as to what secularity consists of. This is why he distinguishes three meanings of secularity and explains that it is the third one that guides his inquiry on secularism in this book. The first meaning of secularity concerns the institutional aspect - represented primarily by the state and public spaces. Taylor asserts that, unlike all pre-modern societies in which the political organization was dependent on adherence to God, in today's secular societies, one can engage fully in politics without ever encountering God; and it is not faith in God, but

* Doktora Adayı, Chicago Üniversitesi, Din Sosyolojisi ve Antropolojisi.

Iletişim: apolat@uchicago.edu, Şemsi Efendi Sok. No: 17 Beylerbeyi, Üsküdar, İstanbul /Türkiye

- DOl: http://dx.doi.org/10.12658/human.society.2.4.R0005 
rationality intrinsic to each sphere of activity that governs public spaces (Taylor, 2007, pp. 1-2). The second meaning of secularity that Taylor notes concerns the "falling off of religious belief and practice," i.e. people turning away from God and religious practice as revealed through lower church attendance (Taylor, 2007, p. 2). Although Taylor's account of these two meanings of secularity resonates with the definition of secularization theory, such as the separation of state and religion and the decline of religion, Taylor intentionally avoids stating it in this way. He disagrees with the linear secularization theory, and "subtraction stories," as will be expanded upon below (Taylor, 2007, p. 22). Instead, Taylor is primarily interested in the third meaning of secularity: the conditions of belief. Although the three meanings of secularity are interrelated, Taylor notes that the fundamental question shaping his inquiry is concerned with the conditions of belief. He states that he wants to "define and trace" the change from "a society in which it was virtually impossible not to believe in God, to one in which faith, even for the staunchest believer, is one human possibility among others" (Taylor, 2007, p. 3). In brief, for Taylor, in order to understand what it means to live in a secular age, one must first and foremost analyze how belief has been an option, "and frequently not the easiest to embrace" (Taylor, 2007, p. 3). Yet, it is also crucial to keep in mind that, for Taylor, this is the case for those living in the North Atlantic world. He voices it at the very beginning of his book that the "we" living in a secular age are those in the North Atlantic.

Taylor's voluminous book is driven by a historical and sociological approach. His historical approach needs to be clarified as a partial historiographical narrative characterized by a set of comparisons drawn between "then" and "now." Taylor prepares himself to answer the question of "why was it virtually impossible not to believe in God in, say, 1500 in our Western society, while in 2000 many of us find this not only easy, but even inescapable?" (Taylor, 2007, p. 25). He weaves the past, the pre-modern, the 1500 s, or simply the "then," as the "enchanted" world and contrasts it with the modern age, the 2000s, or "now." While Taylor emphasizes the changes that took place over these centuries, indeed even emphasizing the differences between the nineteenth and twentieth century, and variations across the decades within the twentieth century, he creates the 1500s and the 2000s as the two markers of the large historical shift to which he is drawing the reader's attention. Yet, also at this point comes the philosophical aspect of Taylor's approach as his analysis of the past is undertaken in terms of shifts occurring in the conception and interpretation of various phenomena, ranging from time, universe, and science to self. The "then," according to Taylor, is the world of the "porous" or vulnerable self, whereas the "now" is that of the "buffered" or disengaged self. The former is the world of collectivity via parish and church, the latter is that of individualism. Whereas the former distinguishes between ordinary and "higher" times, the latter views time as homogenous and empty. As Taylor discusses the factors creating the "now" across centuries from the scientific revolution, the rise of the police state and disciplinary society to the Reformation, deism, and exclusive 
humanism, he also accounts for differences between today and recent centuries, namely the nineteenth and twentieth centuries. In other words, he does not claim that belief and unbelief have always remained same. Yet, he still holds that today, the age of secularity in the West, is one in which belief turned out to be a difficult option as a consequence of historical, sociological, and philosophical shifts.

Taylor offers a historiographical narrative constructed from our perception of the particularity of the present moment, which is driven by an appreciation of overcoming earlier ages. He explains the conditions of belief in a historical narrative because he believes "our sense and understanding of ourselves as secular" emerges out of this sense of "overcoming and rising out of earlier modes of belief" (Taylor, 2007, p. 268): Thus, for Taylor, living in a secular age is intrinsically viewed as an achievement, as overcoming irrational belief and the enchanted world, and this is important to be taken into account in an analysis of secularity. This is why he gives an illustration of secularism through a historical narrative. However, Taylor's account of historical and sociological transformations as well as their accompanying philosophical shifts in the conception of self, world, relationship to God, and so on, is not intended to recount a comprehensive story of all causes leading to the present moment. On the contrary, as he notes, "the story of what happened in the secularization of Western Christendom is so broad, and so multi-faceted," he tries to "give the barest bones of the story" (Taylor, 2007, p. 29). He seeks to convey a number of the major transitions as a story, since, he believes, the fundamental aspect of "our present spiritual predicament" is "historical." That is, as also previously stated, it is "our understanding of ourselves and where we stand is partly defined by our sense of having come to where we are, of having overcome a previous condition" (Taylor, 2007, p. 28).

In this respect, Taylor is not interested in providing an all-inclusive theoretical account of secularity for two reasons. First, he states that he is not concerned with belief and unbelief as theories, but as how they are lived (Taylor, 2007, pp. 4-5, 325). That is to say, for him, it is more important to depict how people live and perceive things instead of how they theorize or reflect on them. In this regard, his assigned role is to highlight this overarching perception that belief in this age is a difficult option, rather than, accounting for the entirety of causes leading to the rise of the secular. Secondly, Taylor rejects a strict causal analysis that seeks to uncover how particular causes inescapably lead to specific outcomes, or how causes and effects are strictly tied. Instead, his goal is to be attentive to unintended consequences, and thereby prefers to trace a "zig-zag account" of the development of the secular age (Taylor, 2007, p. 95). It is a reflection of his view that "all striking human achievements" resist being reduced to the conditions that enabled them (Taylor, 2007, p. 258). ${ }^{1}$

1 He makes this point explicitly in his discussion on the rise of exclusive humanism, but it can be taken as part of his general stance in this book. 
Although Taylor acknowledges that the historical narrative he offers is limited in the sense that it touches on only a select number of the major transitions that have given rise to different facets of secularity, I argue that his narrative is partial at a much deeper level. It is not only a matter of what Taylor chooses to recount in this broad narrative, it is more crucially how Taylor presents the range of phenomena discussed in the book. Taylor tells the story of secularity with our particular sense of the historicity of our contemporary world, which constructs itself in relation to earlier forms of belief and an "enchanted world." Yet, throughout his inquiry, he interweaves his narrative around the axis of "the sense of fullness" (Taylor, 2007, p. 5). Taylor introduces this concept, "the sense of fullness," first in the introduction, where he quotes at length an example from the autobiography of Bede Griffiths, in which Griffiths narrates his experience of hearing the birds and the feeling of awe that occupied him, which made him feel as if he "had never heard birds singing before." It was as if he were standing "in the presence of angels" underneath the sky, "a veil before the face of God" (Taylor, 2007, p. 5). Taylor interprets Griffiths' anecdote as one case of the sense of fullness which "breaks through our ordinary sense of being in the world" (Taylor, 2007, p. 5). Taylor continues by adding how we also experience absence, or loss of the place of fullness, albeit even forgetting what fullness looks like (Taylor, 2007, p. 6). Indeed, he asserts, there is also a middle condition between the two where we find "a way to escape the forms of negation, exile, emptiness, without having reached fullness" (Taylor, 2007, p. 6). Yet, underneath Taylor's focus on the sense of fullness lies his primary concern, that is, whether the source of fullness is immanent or transcendental, "within" or "without," and in what sense (Taylor, 2007, p. 10). Taylor then henceforth sets the framework of his analysis of secularity along the lines of immanence versus transcendence. Taylor notes that although all three senses of secularity refer to "religion," he still asks what religion really is. In this respect, Taylor links his story of "secularization" 2 in the modern West with defining religion through immanent versus transcendental sources of the power that bring the sense of fullness. Reminding us that analysis is specific to modern West, or Latin Christendom, Taylor emphasizes that:

We have moved from a world in which the place of fullness was understood as unproblematically outside of or "beyond" human life, to a conflicted age in which this construal is challenged by others who place it (in a wide range of different ways) "within" human life. (Taylor, 2007, p. 15)

Taylor underlines the fact that he does not propose that this distinction between transcendent and immanent serves as the criterion to define religion's applicability for all societies and ages, but rather only speaks of its validity for North Atlantic, Western culture. In other words, those who criticize Taylor for his failure to refer to the non-

2 He himself calls his engagement with the question of secularity as such, i.e. as telling a story, in the preface. See, Taylor, 2007, preface. 
Western world fail to note that Taylor is very aware of the particularity of the story he narrates and, indeed, intentionally limits it to the "we" in the North Atlantic, or in the "West." That is to say, Taylor approaches secularity and analyzes it as a particular story of those living in the West. He also uses this line of thought to explain the predominance of the transcendental frame in the past versus that of the immanent frame in the modern world. Despite his acknowledgment of his partial story, one might still ask Taylor to what extent the story of the West's achievements may be told irrespective of its relationship with the rest. Furthermore, underneath his recognition of his story's validity for Latin Christendom, Taylor believes this is also a story of achievement, a higher stage achieved by the modern West, to which the rest of human societies has not yet arrived (not surprisingly, Muslim societies constitute a significant portion of his examples in this regard).

Nevertheless, criticisms concerning Taylor's radical compartmentalization and separation of the "we" from all pre-modern and contemporary non-Western and nonChristian societies, might be left aside to comprehend what is really at stake in his approach, namely, why he prioritizes defining religion and secularity, especially what he terms conditions of belief, in terms of what the sense of fullness consists of. I contend that the crux of Taylor's engagement in the question of secularity is this: For Taylor, telling the story of secularity is not just telling a story or recounting a historical narrative describing how secularity emerged and is lived in the modern West. Rather, it is telling a story so that others may take a lesson from it. It emphasizes a theme for both believers and unbelievers, or for both passionate adherents of transcendent and immanent frames. This message becomes radically clearer towards the end of $A$ Secular Age, specifically in parts four and five, where Taylor describes how both transcendence and immanence are "fragile," how both positions are open to "destabilization" by the other, or how they create "cross-pressures" for each other (See, for example, Taylor, 2007, p. 435). Taylor underscores that there is an internal criticism of the closed immanent frame, which draws attention to malaises of immanence, to the sense of emptiness and dissatisfaction, to the modern denial of tragedy, pain, and suffering, or offers an ecological criticism. Taylor notes that, in this regard, even though solutions are still mostly sought within immanence, there is a wide range of options between orthodoxy and unbelief. ${ }^{3}$ It is no longer merely a single dichotomy of belief or orthodox religion versus unbelief or secular humanism.

This also explains why Taylor poses his main question as belief becoming an option among many other options, including various third ways among religious, nonreligious, as well as anti-religious. Although Taylor discusses the factors pushing for the closure or openness of the immanent frame to transcendence, he is foremost 
interested in demonstrating the other way around, namely, how religion (Christianity more specifically) can recompose itself in spite of the enduring challenge or pressure. This point also constitutes Taylor's main disagreement with the secularization theory. ${ }^{4}$ Taylor asserts that it is wrong to talk about secularization as a linear decline of religion over centuries. Religion does not remain constant, and nor do the set of causes or forces undermining it. He underscores that forms of religion have changed and continue to change. Yet, our contemporary situation "is different and unrecognizable to any earlier epoch. It is marked by an unheard of pluralism of outlooks, religious and non- and anti-religious, in which the number of possible positions seems to be increasing without end" (Taylor, 2007, p. 437). It is also the era of a crucial mutual fragilization between belief and unbelief. Thus, Taylor continues, "as a believer" himself he recognizes this sense of 'decline' of religion, whereby "religious belief now exists in a field of choices which include various forms of demurral and rejection; Christian faith exists in a field where there is also a wide range of other spiritual options" (Taylor, 2007, p. 437). However, as he continues, he reveals the more crucial point that interests him:

But the interesting story is not simply one of decline, but also of a new placement of the sacred or spiritual in relation to individual and social life. This new placement is now the occasion for recompositions of spiritual life in new forms [emphasis added], and for new ways of existing both in and out of relation to God (Taylor, 2007, p. 437).

The flipside of Taylor's criticism of secularization theory, and his argument on mutual fragilization with the rise of new configurations on the side of belief and unbelief and the various options between the two, is his criticism of "subtraction stories." Throughout A Secular Age, Taylor challenges "subtraction stories" that explain modernity or secularity emerging naturally once human beings liberate themselves from earlier, confining conceptions, beliefs, horizons, or structures (or once these latter fall away, secularity rises). Taylor underscores that these approaches fail to take into account how Western modernity and secularity are indeed "fruits of new inventions, newly constructed self-understandings and related practices" (Taylor, 2007, p. 22). ${ }^{5}$ Does he also intend to tell that just as we have been innovative in the rise of modernity, we can be innovative to regenerate Christianity? The more Taylor unpacks his historical account of secularization in the West, and underlines what it is like to live as believers and unbelievers, the common and distinct dilemmas and cross-pressures

4 For details of Taylor's endorsement as well as criticism of secularization theory, see Taylor (2007, pp. 423-437).

5 Or, as Taylor puts elsewhere: "The subtraction story gives too little place to the cultural changes wrought by Western modernity, the way in which it has developed new understandings of the self, its place in society, in space and in time. It fails to see how innovative we have been; its tendency is to see modernity as the liberating of a continuing core of belief and desire from an overlay of metaphysical/religious illusion which distorted and inhibited it." (Taylor, 2007, p. 573). 
shared by immanence and transcendence, the clearer the message he wants to give to both sides becomes. And it seems, the answer to the above question is affirmative. In other words, as already stated, the theme or point of Taylor story and of his long detour in A Secular Age, is best revealed towards the end of the book in this quote:

As I have tried to show throughout this book, we [i.e. "Christians" and "secular humanists"] both emerge from the same long process of Reform in Latin Christendom. We are brothers under the skin.

Both sides need a good dose of humility, that is realism [emphasis added]. If the encounter between faith and humanism is carried through in this spirit, we find that both sides are fragilized; and the issue is rather reshaped in a new form: not who has the final decisive argument in its armory - must Christianity crush human flourishing? Must unbelief degrade human life? Rather, it appears as a matter of who can respond most profoundly and convincingly to what are ultimately commonly felt dilemmas. (Taylor, 2007, p. 675)

Thus, I think, one can safely assert that behind all the rigorous philosophical, historical, sociological bases of the secular age that Taylor traces in A Secular Age, is his pragmatic, realistic and prescriptive approach to the issue of secularity when considering what it means to live in a secular age. It tells both Christianity and exclusive humanism how they should acknowledge their mutual fragile conditions and reconstruct themselves to respond to their common dilemmas.

Talal Asad has contributed to serious thinking about secularism across many disciplines, even though his Formations of the Secular, Christianity, Islam, and Modernity begins with a question that seems addressed foremost to anthropologists: "What might an anthropology of secularism look like?" With the first essay in Formations of the Secular, Asad reflects upon anthropologists' negligence to pay closer attention to the topic of secularism, despite their focus on the study of religion. Asad asks in this essay, and in his other writings, whether one can really consider religion without understanding its other, secularism, on which I will elaborate further in the rest of this essay. I argue that although both Taylor and Asad have been very influential scholars for multiple disciplines, Taylor's approach in a Secular Age is predominantly intellectual; whereas, Asad's is anthropological. That is, Asad grounds his inquiry about religion and secular in space and time, instead of approaching the question as a universal, philosophical one. ${ }^{6}$ Furthermore, Asad considers the encounter with and openness to the 'other' in past and in other societies crucial to disclose the particularities, contingencies, and powers of the "secular modern." For him, anthropology as a

6 Asad states that conceptual analysis is as old as philosophy. What distinguished modern anthropology in this regard from philosophy is "the comparison of embedded concepts (representations) between societies differently located in time or space." (Asad, 2003, p. 17). 
"serious study of different modes of being and thinking helps us conceptually" (Scott, 2006, p. 274). It enables us to think about assumptions behind "our most cherished and taken-for-granted notions" (Scott, 2006, p. 274). In this respect, if Asad's approach is pragmatic in any sense close to that of Taylor's, it is to disclose the contradictions of secular liberalism "in order to preserve secularism's virtues without clinging to its vices - in order, that is, to respond creatively and therefore undogmatically to the diverse anti-secularist tendencies throughout the contemporary world" for which he considers anthropologists' openness a critical asset (Asad, 2001, p. 222). However, as he underlines, in his response to Partha Chatterjee in Powers of the Secular Modern, his ultimate political intention is not to discover "new paths toward secularism," but rather to problematize the category of "secular" and explore "what secularism means historically-how certain practices, concepts, and sensibilities have helped to organize, in different places and at different time, political arrangements called secularism" (Asad, 2006, p. 217).

Even though Taylor problematizes aspects of secularization theory that attribute an essential definition to religion and presume its linear decline, and likewise, describe secular as a natural outcome of this process; he still undertakes his inquiry into secularity still mostly through the secularization theory. Taylor draws attention to the varieties of options emerging between the religious and the non-religious, and underscores the limits and potentials of these options between belief and unbelief. In this regard, although Taylor distinguishes between the three forms of secularity and argues that it is the conditions of belief that constitute his main inquiry into the nature of secularity, his study of modern secular age still strongly goes along with the secularization theory. Asad, however, is primarily occupied with examining the "secular" instead of engaging with the secularization theory. His basic dissatisfaction with secularization theory is not whether it is a story of linear decline, or a much more complex account of the rise of secularity. Rather, he is absorbed by the fact that secularization theories do not thoroughly explore what "secular" is (Asad, 2003, p. 183). Asad carefully distinguishes between secular, secularism, and secularization. Although he affirms that they are related, his basic concern is not to explore the "secular" through secularization but rather through its "Siamese twin:" religious (Asad, 2001, p. 221). According to Asad, "the secular" is conceptually prior to the political doctrine of "secularism." That is to say, he engages with the question of how "over time a variety of concepts, practices, and sensibilities have come together to form 'the secular'" (Asad, 2003, p. 16). ${ }^{7}$

7 Also, for his answer to the question posed to him about this in the interview conducted by David Scott, published at the end of Powers of the Secular Modern, see Scott (2006, p. 302). Scott asks "what is the relationship between the secular as an epistemic category, secularism as a political doctrine, and secularization as a historical process?" Asad answers by explaining what he was trying to do in this regard in the three sections of the Formations of the Secular, secular, secularism, and secularization. 
In this regard, Asad also does not believe that secularism is "an intellectual answer" dedicated to the promotion of "social peace and toleration" (Asad, 2003, p. 5). He instead defines it as "an enactment by which a political medium (representation of citizenship) redefines and transcends particular and differentiating practices of the self that are articulated through class, gender, and religion" (Asad, 2003, p. 5). Thus, secularism is one of the principles that modernity seeks to institutionalize. Asad highlights that "modernity" is neither "a totally coherent object nor a clearly bounded one," but it is a "project" or "a series of interlinked projects" that has become "hegemonic as a political goal" (Asad, 2003, p. 13). His interest in the question of secularism and modernity lies in understanding "the attempt to construct categories of the secular and the religious in terms of which modern living is required to take place, and non-modern peoples are invited to assess their adequacy" (Asad, 2003, p. 14). Thus, unlike Taylor, for Asad, the issue is not one of "multiple modernities," or limiting the story of secularity to the "we" in the North Atlantic and then expanding it. Rather, it is important from the very beginning to grasp the salience of non-European and non-Western peoples' histories for the construction of the project of modernity. ${ }^{8}$ Asad does not intend to provide a historical account of secularization by uniting Western and non-Western histories. He seeks to identify major historical shifts that came to shape secular sensibilities, attitudes, practices in the West and elsewhere.

Unlike Taylor, Asad does not undertake a historical narrative of secularization. His approach is genealogical in tracing the formations of modern religion and secularity. Asad defines genealogy as "a way of working back from our present to the contingencies that have come together to give us our certainties" (Asad, 2003, p. 16). ${ }^{9} \mathrm{He}$ expands on his genealogical method in his response to José Casanova's essay in Powers of the Secular Modern, entitled "Secularization Revisited: A Reply to Talal Asad." In this essay, after quoting a passage from Formations of the Secular in which Asad refers to humanism, the Enlightenment concept of nature, and Hegel's philosophy of history in tracing the concept of the secular, Casanova asserts that Asad fails to recognize the extent to which the formation of the secular is linked with the Protestant Reformation (Casanova, 2006, p. 21). In his response to Casanova, Asad underlines that he "tried not to describe historical development here in terms of a linear sequence of ideas," which identifies one factor as a cause and then secular modernity as its effect, since "a genealogical investigation presupposes a more complicated web of connections and recursivities than the notion of a causal chain does" (Asad, 2006, p. 210). As

8 For Asad's answer to the question "why does the conception of modernity become so crucial for you, and what concept of modernity is important to you?" See Scott (2006, pp. 291-294).

9 For Asad's response to David Scott's point about the contradiction embedded in his work being attached to both genealogy and tradition, i.e. to both Michael Foucault and Alasdair Maclntyre, see Asad (2006, pp. 233-235). 
revealed in his response to Casanova, Asad's investigative method is also strikingly different from Taylor's. Taylor by no means claims to be exhaustive, and is attentive to unintended consequences; however, he still pursues an investigation of causes and factors leading to a secular age and society. Asad remains genealogical in both Genealogies of Religion and Formations of the Secular in his study of religion and the secular. Nevertheless, both Asad and Taylor seek to bring into attention the peculiarities of the present moment, the distinctiveness of modern conceptions.

In addition to drawing a historical narrative of secularity versus pursuing a genealogical investigation of accidental processes and contingencies, one main difference between Taylor and Asad's approaches revolves around the question of working through a definition of religion or not. Taylor grounds his study of the development and transformation of Western secularity on a specific definition of religion. He indexes religion in terms of "the sense of fullness" and focuses on the changing conditions of belief and unbelief that render the former a difficult option. Asad, to the contrary, especially in his earlier works, draws attention to the kinds of problems embedded in offering universal, essentialist definitions of religion. In Formations of the Secular and later works, he more extensively discusses the mutual dependence and tension between religion and secular, and does not attribute an essence to either.

Asad acknowledges the "religious" and the "secular" to be unfixed categories. He argues that "the secular is neither continuous with the religious that supposedly preceded it," "nor a simple break from it" (Asad, 2003, p. 25). Likewise, he asserts "the secular is neither singular in origin nor stable in its historical identity, although it works through a series of particular oppositions" (Asad, 2003, p. 25). As he rejects essentialist definitions of both religion and the secular, Asad underlines that he considers it crucial to analyze the two categories together. In responding to the question of how he thinks his two books Genealogies of Religion and Formations of the Secular relate to one another, he states that they follow one another. More than that, the latter also undertakes a seemingly paradoxical endeavor. He states that Formations of the Secular problematizes the clear-cut separation of "the religious" and "the secular" but also looks for "the conditions in which they were clear-cut and were sustained as such" (Scott, 2006, p. 298). In Genealogies of Religion, Asad examines how religion came to be defined as a "transhistorical and transcultural phenomenon" as a consequence of historical shifts that, among others, claimed that religion has an autonomous essence, distinct from that of politics, common sense, or science, that can be analytically identified (Asad, 1993, p. 28). Through a critical engagement with Clifford Geertz's definition of religion, Asad underscores that "there cannot be a universal definition of religion, not only because its constituent elements and relationships are historically specific, but because that definition is itself the historical product of discursive processes" (Asad, 1993, p. 29). It is very important to grasp how Asad, through his engagement 
with Geertz, elucidates on the problems embedded in an essentialist definition of religion; whereby he also investigates how religion is constructed as an anthropological category that prioritizes "belief."

Asad's reading of Wilfred Cantwell Smith's book The Meaning and End of Religion, a book that refutes essentialist approaches to religion, is strikingly very similar to his criticism of Geertz. His engagement with these two different texts around one main axis brings into light the significance of the notion of practice in Asad's thinking and approach. Asad defines practice in his essay on Smith's book, as follows: "By practice, I refer here to activity that depends on the developed capacities, the cultivated sensorium, of the living body and that, in its engagement with material objects and social conditions, makes meaningful experience possible" (Asad, 2001, p. 209). In his engagement with both Geertz and Smith, as well as, with Taylor, Asad disassociates his approach from both essentialist, functionalist and interpretive approaches (Asad, 2006, p. 212). It is because for him practices, modes of living, and not just how people think and interpret, but how they live and act are crucial for investigation. Even though, in A Secular Age, Taylor emphasizes studying secularity in terms of how things are lived, not just theorized, he undertakes a primarily intellectual, philosophical analysis of identifying the shifts in the conceptions and interpretations of the self, nature, time, agency etcetera, without questioning the body-mind distinction. However, Asad not only unpacks the problems with this distinction, but also pointedly does not universalize body and mind.

This is because, for Asad, habitus, tradition, and authority are intrinsically related with one another. For him, practices, as habitus and as predispositions of the body, are crucial for any investigation of how things are lived. Furthermore, it is not "the body" and "the mind" but bodies and minds as belonging to the traditions which discipline them and which teach them about proper thinking and conduct. It is not the universal bodyand-mind but the salience of different traditions of embodiment for mediating the human experience. Asad's conception of tradition is significantly influenced by that of Alasdair Maclntyre, (as best seen first in his essay on "the Idea of an Anthropology of Islam" where he discusses Islam as a discursive tradition) (Asad, 1986). However, in distinction to Maclntyre, Asad then articulates on tradition not merely as an extended debate, and argumentation, but via embodiment, habitus, and discipline. Hence Asad interconnects Marcel Mauss' concept of habitus directly to his conception of tradition. ${ }^{10} \mathrm{He}$ brings up the centrality of learning and teaching practices, their aims, proper performances, and so on. As one identifies these key constitutive features of Asad's thinking, it becomes much easier to grasp several chapters of Genealogies of

10 David Scott's interview with Asad provides one of the best and clearest accounts of underlying themes, concepts, and questions of Asad's thinking, including its contradictions. On habitus and the embodied nature of tradition, see Scott (2006, pp. 288-289). 
Religion and Formations of Secular. ${ }^{11}$ It also becomes clearer to see how his former students carry this approach further, as revealed through Asad's own references to Saba Mahmood's and Charles Hirschkind's works, in his essay on Smith and elsewhere. In short, for Asad, embodiment, body and its materialities, as well as the conditions that enable them, are indispensable to his inquiry into religious and the secular.

All of this comes together in Asad's critique of Geertz, not on an individual basis but as an exemplary of interpretive approaches. What lies at the heart of Asad's criticism is Geertz' "cognitivist orientation"12 driven by a sharp body-mind distinction that assumes the autonomy of signs, (Asad, 2006, p. 211) disregards how the body is "enmeshed in traditions of cultivation" and ignores the body and the subject as "teachable," or having the capacity to be taught (Asad, 2006, p. 287). Thus, Asad does not draw attention to Geertz's, and many other scholars,' focus on belief at the center of religion as a distinctively modern phenomenon, in order to advocate a call for studies that emphasize both belief and practice. His main approach is, by presenting the problems inherent in the sharp body and mind distinction, to dismantle prioritizing belief "as a state of mind, rather than constituting activity in the world" (Asad, 1993, p. 47). In this regard, for him, tradition is not merely a cognitive framework, but "a practical mode of living". It is about "techniques for teaching body and mind how to cultivate specific virtues and abilities that have been authorized, passed on, and reformulated down the generations" (Asad, 2001, p. 216).

Ultimately, Asad is critical of interpretive approaches, including Taylor's, because for him the question of embodiment and tradition is fundamental; that is, to take into account how different traditions of embodiment mediate the interpretation of experience. Likewise, he is not primarily interested in how signs or concepts are interpreted, but how they are lived, what these signs and concepts do, and how they are used. That is why Taylor and Asad diverge in what they embrace from Ludwig Wittgenstein. Taylor embraces Wittgenstein's "picture" and throughout A Secular Age seeks to disclose the shifts and disruptions in our background to explain an age and society in which people can no longer "naively" believe (Taylor, 2007, pp. 13-14, 549). Asad, however, refers to Wittgenstein's "grammar of concepts" to emphasize the significance of the use of concepts, rather than their meanings and interpretations. As he states in Formations of the Secular, his intention is not merely to show the contingencies of the concepts "the religious" and "the secular," but how these "contingencies relate to changes in the grammar of concepts;" that is, how changes in concepts play out and how they "articulate changes in practices" (Asad, 2003, p. 25). For Asad, the issues of power and authority are both indispensable to the study of practice. He considers it essential to examine the conditions of possibilities of symbols, acts, and practices. He underlines the significance of the question of how interpretations of symbols are

11 For Asad's own review of the chapters of Genealogies in this regard, see Asad (2006, p. 212).

12 This is how David Scott expresses it; see Scott (2006, p. 287). 
authorized; how proper, correct readings of symbols and acts are learned and reproduced (without assuming that they are static and unchanging).

Finally, Asad's analysis remains rather weak and incomplete in illustrating how modern academic study of religion and secular, as well as how the variety of concepts, practices, and sensibilities that have come together to form "the secular" relate to the issue of politics and the modern state. In other words, as David Scott asks him, "what is the relationship between the secular as an epistemic category, secularism as a political doctrine, and secularization as a historical process?" (Scott, 2006, p. 302). As Asad acknowledges, he has not satisfactorily demonstrated how the secular and legal reform are related (Scott, 2006, p. 302), nor has he thoroughly addressed in Genealogies of Religion and Formations of the Secular what consequences defining religion in terms of belief create politically. ${ }^{13}$

In this article, I have tried to portray the basic features and differences of Taylor and Asad's approaches to the issue of secularity. I think that Taylor's approach is ultimately a pragmatic, goal oriented, philosophical inquiry; whereas Asad's is an anthropological one driven with critical reflections on Western liberalism. Taylor tells a historical narrative of secularity because he believes our sense of overcoming earlier ages is fundamental to our contemporary perceptions. In this narrative, he traces the shifts in our background through the lens of the sense of fullness, which arrives at a multiplicity of options concerning belief and unbelief. His story is central to his prescription. Orthodox Christianity and exclusive humanism are both under pressure; yet, they should refigure themselves, as they have already partly done. For Asad, secularity cannot be considered independent of the powers of liberalism and the modern state. In his approach however, it is crucial to distinguish the political doctrine of secularism and the secular and to examine the secular together with religion without attributing any essentialist or fixed definition to either. According to Asad, religion and secular do not have an unchanging essence. However, his main concern is not to trace the continuities and discontinuities, an approach closer to that of Taylor, but rather to underscore how what constituted religion in the past had been part of a map of elements that is not only different today, but which is embodied, authorized, and played out differently, and therefore constitutes different selves.

13 This last question is based on my reading of how Asad describes it in his recent article entitled Thinking about Religious Belief and Politics. In this essay, Asad explicitly reviews and engages with Taylor's A Secular Age. This essay must be read by anyone who is interested in understanding how Asad reflects on Taylor's work as well as how he summarizes his own perspective and approach. See Asad (2012). I worked on earlier versions of this paper before Asad's article was published. Although reading the article makes me feel much more confident about my treatment of his approach, I have purposefully chosen to leave it to the reader to read and compare this article and Asad's own article. Furthermore, since I take it as an ongoing conversation, I prefer not to extensively cite Asad's essay on Taylor at this stage; that is, before Taylor formally expresses his own views and poses his questions in response to Asad. 


\section{References}

Asad, T. (1986). The idea of an anthropology of Islam [occasional papers]. Washington, D.C.: Georgetown University, and Center for Contemporary Arab Studies.

Asad, T. (1993). Genealogies of religion: Discipline and reasons of power in Christianity and Islam. Baltimore and London: The John Hopkins University Press.

Asad, T. (2001). Reading a modern classic: W. C. Smith's "the meaning and end of religion." History of Religions, 40(3), 205-222.

Asad, T. (2003). Formations of the secular: Christianity, Islam, modernity. Stanford, California: Stanford University Press.

Asad, T. (2006). Responses. In D. Scott, \& C. Hirschkind (Eds.), Powers of the Secular Modern: Talal Asad and His Interlocutors (pp. 206-241). Stanford, California: Stanford University Press.

Asad, T. (2012). Thining about religion, belief, and politics. In R. A. Orsi (Ed.), The Cambridge companion to religious studies (pp. 36-58). New York: Cambridge University Press.

Casanova, J. (2006). Secularization revisited: A reply to Talal Asad. In D. Scott, \& C. Hirschkind (Eds.), Powers of the secular modern: Talal Asad and His Interlocutors (pp. 12-31). Stanford, California: Stanford University Press.

Scott, D. (2006). Appendix: the Trouble of Thinking: An Interview with Talal Asad. In D. Scott \& C. Hirschkind (Eds.), Powers of the Secular Modern: Talal Asad and His Interlocutors (pp. 243-303). Stanford, California: Stanford University Press.

Scott, D. \& Hirschkind, C. (Eds.). (2006). Powers of the Secular Modern: Talal Asad and His Interlocutors. Stanford. California: Stanford University Press.

Taylor, C. (2007). A secular age. Cambridge, Massachusetts, and London, England: The Belknap Press of Harvard University Press. 